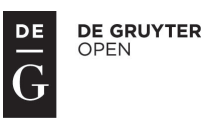

\title{
CONVERGENCE BETWEEN KAZAKHSTAN'S FINANCIAL SYSTEMAND INTERNATIONAL STANDARDS: OVERCOMING DIFFICULTIES
}

\author{
Natalya Uvarova ${ }^{1}$
}

\begin{abstract}
This article deals with the convergence of the Kazakh financial system with international standards in light of the new, enhanced agreement with the European Union on partnership and cooperation (January 19, 2015). Based on this research, the approaches used by the Kazakh financial system to converge with the European Union (EU) and the mechanism of implementing international standards in the national regulatory framework are determined. In practice, the study provides justification for the necessity of arranging the systematization of existing rules and regulations covering financial activity in the Republic, eliminating discrepancies between the national regulatory framework and international standards, and determining clear security guarantees for foreign investors' financial activity in the Republic. The research results are primarily focused on the development of public finance management theory. Theories and conclusions present in the study can be used in the educational processes of economic and legal institutions and in the policymaking activity of public finance management bodies.
\end{abstract}

\section{Keywords}

Finance, International Standards, Public Management, Global Financial System, Financial Standards, Regulation

\section{Introduction}

International practice contains certain standards (rules, regulations, guidelines, and prohibitions) for corporate economic and financial activities, as well as measures to prevent these rules from being violated. Official standards are decided under the influence of international organizations (the UN and the Council of Europe) and therefore are determined by the transnational nature of corporate violations of economic and financial rules.

${ }^{1}$ Department of Accounting and Auditing, Caspian University, Seifullin avenue 521, Almaty, Republic of Kazakhstan. E-mail: uvarova.natalya@yahoo.com. 
International standards play an important functional role, and they not only serve as official reference points for national financial standards to reach during convergence but also provide a foundation for integration processes between countries in the sphere of finance and economics.

\section{Prerequisites for convergence of the Kazakh financial system with EU directives}

The Kazakh financial system's need for convergence with international standards and EU directives can be explained by both objective and subjective factors. The objective factors stem from demand for the Republic's socioeconomic development, the economy's progressive growth based on market principles, and the creation of favorable conditions for its integration into European and global economic systems. The EU and Kazakhstan are strategic trade partners. Former European Commissioner for External Relations and European Policy Benita Ferrero-Waldner notes that: "Kazakhstan is an important partner for the EU in Central Asia. We keep the democratic and economic reforms, to strengthen cooperation in the energy field, based on our well-developed trade relations and seek new ways to jointly promote regional stability in Central Asia". ${ }^{2}$ In turn, Kazakhstan adopted the "Path to Europe" state program. ${ }^{3}$

The subjective factors are associated with state financial policy aimed at the formation of the Republic's financial infrastructure, development of the financial sector and its individual segments within the country, and the establishment of a competitive national financial system and its convergence with international rules and EU directives.

Kazakhstan's financial system is integrated into the global financial system. Therefore, specialized international financial organizations have significant impact on the Kazakh financial sector's stability, formation, and consolidation, as do their decisions and recommendations. In this regard, it is particularly important for Kazakhstan to be a member of international financial organizations such as the International Monetary Fund, International Bank for Reconstruction and Development, International Finance Corporation, International Development Association, Multilateral Investment Guarantee Agency, International Center for Settlement of Investment Disputes, European Bank of Reconstruction and Development, Asian Development Bank, Islamic Development Bank ${ }^{4}$, World Bank, World Bank Group, German Agency for International Cooperation, etc.

Naturally, questions arise concerning the uniformity and interrelation of international standards and EU directives on the one hand, and the rules governing financial relations in the Republic on the other. The problem's theoretical significance is associated with the development of an updated version of financial management theory, whereas the practical significance resides in the efficient operation of public authorities and financial institutions, so that the financial system's regulatory framework would form in line with the country's

\footnotetext{
${ }^{2}$ European Commission (2006).

${ }^{3}$ Decree of the President of the Republic of Kazakhstan dated August 29, 2008, N 653 On the state program "Path to Europe" for 2009-2011.

${ }^{4}$ Law of the Republic of Kazakhstan dated December 6, 2001, No. 264-II.
} 
ongoing socioeconomic reforms and thereby would contribute to the convergence of the Republic's financial system with international standards and EU directives.

Strictly speaking, international standards are not mandatory for Kazakhstan in all cases; they are more like non-regulatory international documents that are not designed to intervene in a country's domestic financial system. For example, the UN Economic and Social Council is the central forum for discussing international economic and social issues of a global or cross-sectoral nature, and thus it develops policy recommendations for the UN member states on these issues.

The Constitution of the Republic of Kazakhstan (Article 4) states that international treaties ratified by the Republic have priority over its domestic laws and are applied directly unless a treaty states that its application requires the issue of a law. ${ }^{5}$ In this case, a constitutional position is formulated and applied to practically enact the prioritized and direct force of an international treaty ratified by the Republic of Kazakhstan on its territory. This also applies to international standards and regulations in the financial and economic spheres. In other words, international standards serve as a reference point for optimizing the Kazakh financial sector's regulatory framework. This involves not only the implementation of relevant socioeconomic reforms and economic restructuring in the Republic but also the modernization of the Republic's financial policy and national financial system as a whole. The procedure by which international standards are integrated into the regulatory framework of the Republic's financial sector and the introduction of acknowledged standards into the national financial legislative system are of practical importance. Implementing and applying international standards at the domestic level requires direct administrative and procedural support. Therefore, a special protocol needs to be adopted that would expand the meaning, content, and application of international standards (regulations and rules) and international treaties of the Republic of Kazakhstan in the financial and economic spheres (direct and indirect transformations, incorporation, reference to an international treaty, and convention). Moreover, developing a procedure for resolving potential conflicts between the decision of an international financial organization that is mandatory for Kazakhstan to implement and the Republic's own regulatory acts is necessary. It is clear that, in this case, the general rule applies; this means that the international financial organization's decision is in force until any such conflict is resolved.

The Kazakh financial system's convergence with international standards and EU directives cannot be regarded as a mechanical process. Such convergence should only be undertaken where absolutely necessary, without disturbing national legal traditions or the Republic's interests. One objective factor dictating the need for the Kazakh financial system's convergence with the rules of the European Union is the harmonization of the Republic's external economic activity in terms of goods, works, and services specifications. In this aspect, the focus should be on those works and services that most require this type of convergence. In practice, convergence needs to occur in the 12 following areas: (1) international regulations and the rules of the European Union of the regulatory framework for enterprises and entrepreneurship; (2) banking operations; (3) accounting and company taxation; (4)

$\overline{5}$ The Constitution of the Republic of Kazakhstan. 
occupational safety; (5) financial services; (6) rules of competition; (7) human, animal, and plant health protection; (8) environmental protection; (9) consumer rights protection; (10) customs regulations; (11) technical regulations and standards; and (12) elimination of discrepancies in metrology, standardization, and certification.

A specific procedure is required to deal with the conditions that affect the establishment and operation of Kazakh companies abroad, especially in the European Union (EU), and accordingly, the same is true for European companies operating in Kazakhstan. This further applies to providing private individuals and legal entities of the other party with discrimination-free access to competent courts and public authorities so that their individual rights in the financial and economic spheres, including proprietary rights, will be protected.

In reality, the inconsistency between the Kazakh regulatory framework for financial and economic issues and, for example, European standards creates an opportunity for disputes. This may involve Kazakh companies operating in the European market, where they can be held responsible for violations of various EU rules and regulations (environmental, tax, and competition). Such actions are regarded as criminal, although no penal code in the EU, save for various directives and public sanctions (fines and suspension of operations), deals with these violations. All this requires managers of companies operating in the European market and in other countries to perform a preliminary study of the rules (regulations and directives) in force in the relevant business sector.

\section{Modernization of the Kazakh financial system}

We can safely assume that many international rules and regulations have previously been implemented in the regulatory framework of the Kazakh financial system, e.g., in bill circulation $^{6}$ and the security market ${ }^{7}$. This suggests that a positive process exists for the Republic's financial system to converge with international standards. Considering international standards and rules, as well as the decisions and recommendations of international financial organizations, the key directions for the modernization of the Kazakh financial system can be determined. First and foremost is the convergence of monetary policy with EU standards. For example, a quarterly review and establishment of an official refinancing rate as one of the main tools for regulating currency liquidity and inflation were put into practice; in addition, calculation methods for minimum reserve requirements for secondtier banks were improved in order to ensure banks' financial stability and the development of the domestic debt market.

Currency relations were liberalized in the Republic in order to shift to the principles of full national currency convertibility and develop the domestic exchange market. Some restrictions on the most attractive and economically viable currency operations were lifted. For instance, the licensing of direct and foreign investments made by banks and insurance companies was abolished; procedures for foreign investment through organizations engaged in professional activities on the security market were simplified; in addition, the

\footnotetext{
${ }^{6}$ Law of the Republic of Kazakhstan dated April 28, 1997, No. 97-1.

${ }^{7}$ Law of the Republic of Kazakhstan dated July 2, 2003, No. 461.
} 
requirement that legal entities obtain a license to open an account in foreign banks was abolished.

Loan offices grew stronger in the Republic. To encourage small businesses and microbusinesses to leave the shadow economy, a three-tier loan scheme was created. This involves banks and organizations providing certain banking services and micro-credit activities; operations performed by micro-credit organizations are excluded from the list of licensed activities.

It was considered advisable to initiate the regulation of "banking conglomerates" in order to limit the risks that can affect banks and other members of the conglomerate and ensure the stability of the banking sector and the Kazakh financial system as a whole. In this regard, the requirements for a major participant of a bank and the acquisition of bank holding status were strengthened, as were the requirements for transparency by the major participant or bank holding company. Restrictions were imposed on the investment activities of a bank or bank holding. In addition, a consolidated supervision of banking activities was set.

Financial authorities initiated the development of a memorandum on cooperation and collaboration to enhance the transparency of banking activities. This creates an opportunity to disclose a bank's real owners, list the organizations controlled by the bank, reveal the bank's affiliates and transactions among them, and present the bank's business development strategy.

To create an effective financial structure in Kazakhstan and enhance public confidence in the domestic financial system, a scheme of actions during systemic risk increases in the financial market was created. Considering the standards of the EU and the further implementation of international supervision standards of the Basel Committee on Banking Supervision, the International Association of Insurance Supervisors, and the International Organization of Securities Commissions, a regulatory framework was created in the Republic involving a prudential regulation of financial institutions, risk management in these institutions, and consolidated supervision.

As part of the Kazakh banking sector's regulatory convergence with international standards, measures were taken to undertake the transition of the Kazakh banking system to the new capital adequacy agreement proposed by the Basel Committee on Banking Supervision, International Convergence of Capital Measurement and Capital Standards (Basel II).

The first loan office was created and now operates in the Republic. It deals with issues such as improving banking services and building public confidence in banks and other financial institutions, safeguarding the interests of borrowers and banks, and reducing risks in the credit services market. In general, the loan office's activity is aimed at ensuring the transparency and security of the credit services market and reducing the costs for borrowers to collect information when they obtain credit.

The Republic also introduced a system for the mandatory safeguarding of private individuals' deposits in second-tier banks. In addition, the national deposit protection scheme meets the international deposit insurance standards recommended by the International Monetary Fund and Financial Stability Forum. 
Note that a range of compulsory insurance types was introduced. For the practical arrangement of work, the Insurance Payment Guarantee Fund, State Annuity Company, and the State Export and Import Insurance Agency were established, and opportunities for foreign firms in the domestic insurance market were extended.

A securities market is being successfully established in the Republic. For this segment of the financial system, the necessary legal framework was created to provide the mechanism for attracting household savings (non-professional investors) through collective forms of investment. $^{8}$

To improve and increase the efficiency of public investments and to assist in attracting foreign and domestic investment ${ }^{9}$, development institutes were established - in particular, financial and service development institutions such as the Kazakhstan Development Bank, Kazakhstan Investment Fund, National Innovation Fund, Small Business Development Fund, State Export and Import Insurance Agency, Engineering and Technology Transfer Center, and Marketing and Analytical Research Center.

To increase the level of competition in the banking services market, non-bank institutions have also had their regulation systems liberalized, thereby reducing excessive state influence over their activities, including in terms of licensing. For example, the requirement for prior consent from the Agency of Financial Supervision to open bank branches, representative offices of resident banks, and representative offices of non-resident banks was eliminated.

The Almaty Regional Financial Center was established and entrusted with developing the securities market, providing integration with international capital markets, attracting investment in the Republic's economy, and introducing Kazakh capital to foreign securities markets.

The Kazakhstan 2050 Strategy sets out the next stage in modernizing the national financial system to ensure the Republic's economic development and its synchronization with the dynamic international financial environment. This refers to enhancing the competitiveness of the Republic's financial system in all core segments. To that end, Kazakhstan adopted the Concept of the Development of the Financial Sector Up To 2030. ${ }^{10}$ The main directions in terms of improving the financial legislation are the modernization of tax rules. Taxation rules require particular improvement because clear taxation rules and regulations are key factors leading to an improved investment climate and attracting domestic and foreign investors. In this aspect, Integrated European experience and specialized research on taxation (especially methodological research ${ }^{11}$ ) are very useful for the development of the Kazakh financial sector. Also, a key role is played by research into the stability of the currency throughout the Eurozone, economic and legal methods to influence the fiscal discipline of EU Member States ${ }^{12}$; the global crisis and the mechanism of economic

\footnotetext{
${ }^{8}$ Law of the Republic of Kazakhstan dated May 13, 2003, No. 415.

${ }^{9}$ Law of the Republic of Kazakhstan dated July 4, 2003, No. 474.

${ }^{10}$ Resolution of the Government of the Republic of Kazakhstan dated August 27, 2014, No. 954.

${ }^{11}$ Kotlan, Machova (2012).

${ }^{12}$ Kacaljak (2011).
} 
recovery in the Eurozone ${ }^{13}$; the application of standards and guidelines in the context of new modes of governance in Europe $^{14}$; etc.

Customs affairs should develop with the aims of (1) simplifying customs procedures in order to eliminate discrepancies in customs regulations and procedures, which can hinder the development of international trade and exchange, and (2) stimulating international cooperation. This requires: the reduction of administrative barriers; application of modern customs administration methods; maximization of the use of information technology; and the introduction of international customs standards so as to ensure predictability, consistency, and transparency when applying customs rules and procedures. The financial sector, natural monopoly sphere, and securities market also require further improvement. A prerequisite for the Kazakh financial system's convergence with European standards is the elimination of contradictions between the domestic and foreign financial sectors and EU regulatory frameworks and clear safeguards against unlawful actions by public agencies and their executives toward economic entities (both residents and non-residents) conducting entrepreneurial activity in the Republic. These steps are essential for partnerships with Western companies. The fact is that international business practices currently recognize the principle of "legal certainty". This involves the maximum transparency of national legislation governing financial and entrepreneurial activities of legal entities, free access to this legislation, and instructions regarding legal restrictions on legal entities activity, as well as the sanctions for their violation.

All this proves the need to systematize the existing regulations and rules of financial activity in Kazakhstan, fill gaps in the regulation of financial relations, simplify registration and licensing procedures for entrepreneurial activity by private individuals and legal entities, and impose restrictions on unlawful interference by public authorities in the activities of commercial and non-commercial financial institutions. The problem of financial activity forecasting and analytic procurement requires special attention. Such activity should be based on the constant monitoring of trends in the global financial sector and its individual segments, the Republic, and the global financial system, and the analysis of various financial institutions' practices. On the one hand, this will allow the ascertaining of the actual situation of the regulations governing the Republic's entire financial sector, and on the other, will reveal the gaps in the penal system relating to economic entities' violations of various financial regulations and rules. A positive solution to this problem is essential in order to attract foreign investors to the Kazakh market.

\section{Conclusion}

The Agreement on an expanded partnership and cooperation between Kazakhstan and the European Union (2015) ${ }^{15}$ creates a fundamental basis for the development of bilateral relations in various areas of mutual interest on the basis of the "EU Strategy for a New Partnership with Central Asia". ${ }^{16}$ In turn, according to the President of Kazakhstan,

\footnotetext{
${ }^{13}$ Stiblar (2011).

${ }^{14}$ Borzel (2011).

${ }^{15}$ Decree of the President of the Republic of Kazakhstan dated January 19, 2015, No. 991.

${ }^{16}$ European Council (2007).
} 
"Kazakhstan is ready to become a gateway for the EU in Central Asia". ${ }^{17}$ The Prospects for EU-Kazakhstan Partnership implies an intensification of work on the convergence of the financial system of the Republic with international standards and EU directives. All parties agreed on the need to reduce the differences between them in the areas of technical regulation, legal metrology, standardization, market surveillance, accreditation, etc.

On the basis of the analysis of the objective and subjective factors affecting the Kazakh financial system's convergence with international standards and EU directives, we can now proceed with the generalizations as follows:

First, with regard to convergence between the Kazakh financial system and international standards, EU directives require a mechanism to implement the required changes in the national regulatory framework in compliance with the Kazakhstan 2050 Strategy and Concept of Financial Sector Development Up To 2030. Modernizing the Republic's financial system involves a complex mix of urgent practical measures aimed at systematizing the existing rules and regulations governing financial activity in the Republic of Kazakhstan; eliminating discrepancies between the national regulatory framework and international standards; and maintaining the stability of the Republic's financial sector and overall economy.

Second, a prerequisite for the convergence of the Kazakh financial system with that of Western countries is the establishment of clear security guarantees for foreign investors' financial activity in the Republic and measures against unlawful actions by public agencies and their executives toward economic entities. This means that the Republic's financial sector's regulatory framework must be available to foreign investors, and its transparency is a prerequisite for meeting the international principle of "legal certainty".

\section{References}

Borzel, T. (2011). Move closer! New Modes of Governance and Accession to the European Union. DANUBE: Law and Economics Review, 2(2), 1-22.

Decree of the President of the Republic of Kazakhstan dated August 29, 2008, N 653 On the state program "Path to Europe" for 2009-2011. SAPP RK. 2008. No. 37. Art. 398.

Decree of the President of the Republic of Kazakhstan dated January 19, 2015. No. 991 About the initialling of the draft Agreement on enhanced partnership and cooperation between Kazakhstan and the European Union. Retrieved on January 19, 2015 from http://adilet.zan.kz/rus/docs/U1500000991.

European Commission. (2006). Commissioner Ferrero-Waldner to visit Kazakhstan 19/20 October. Press Release Database IP/06/1420, Brussels, 18 October, 2006. Retrieved on October 18, 2006 from http://europa.eu/rapid/press-release_IP-06-1420_en.htm.

European Council. (2007). The Regional Strategy Paper for Assistance to Central Asia (2007-2013). Retrieved from http://www.eeas.europa.eu/central_asia/rsp/07_13_en.pdf. Kacaljak, M. (2011). The Debt Crisis and the Means of Enforcing the Budgetary Discipline of EU Member States. DANUBE: Law and Economics Review, 2(4), 63-79.

\footnotetext{
${ }^{17}$ Nazarbayev (2010).
} 
Kotlan, I., Machova, Z. (2012). World Tax Index: Methodology and Data. DANUBE: Law and Economics Review, 3(2), 19-33.

Law of the Republic of Kazakhstan dated April 28, 1997, No. 97-1 "On bill circulation in the Republic of Kazakhstan". Bulletin of the Parliament of the Republic of Kazakhstan. 1997. No. 8. P. 87; 2001. No. 24. P. 338.

Law of the Republic of Kazakhstan dated December 6, 2001, No. 264-II "On the membership of the Republic of Kazakhstan in the International Monetary Fund, International Bank for Reconstruction and Development, International Finance Corporation, International Development Association, Multilateral Investment Guarantee Agency, International Center for Settlement of Investment Disputes, European Bank of Reconstruction and Development, Asian Development Bank, Islamic Development Bank". Bulletin of the Parliament of the Republic of Kazakhstan. 2001. No. 23. P. 313.

Law of the Republic of Kazakhstan dated July 2, 2003, No. 461 "On security market". Bulletin of the Parliament of the Republic of Kazakhstan. 2003. No. 14. P. 119.

Law of the Republic of Kazakhstan dated July 4, 2003, No. 474 "On state regulation and supervision of the financial market and financial organizations". Bulletin of the Parliament of the Republic of Kazakhstan. 2003. No. 15. P. 132.

Law of the Republic of Kazakhstan dated May 13, 2003, No. 415 "On joint stock companies". Bulletin of the Parliament of the Republic of Kazakhstan. 2003. No. 10. P. 55.

Nazarbayev, N. (2010). Kazakhstan is ready to become the EU "gateway" to Central Asia. Diapazon, April 11, 2010. Retrieved from http://www.diapazon.kz/kazakhstan/kazpolitics/26735-kazakhstan-gotov-stat-dlja-es-vorotami-v.html.

Resolution of the Government of the Republic of Kazakhstan dated August 27, 2014, No. 954 "On Approval of the Concept of Development the Financial Sector of the Republic of Kazakhstan Up To 2030”. Retrieved on August 27, 2014 from http://adilet.zan.kz/rus/docs/ P1400000954.

Stiblar, F. (2011). The Global Crisis and the Western Balkans. DANUBE: Law and Economics Review, 2(3), 23-46.

The Constitution of the Republic of Kazakhstan, adopted at the Republican Referendum on August 30, 1995. Bulletin of the Parliament of the Republic of Kazakhstan. 1996. No. 4. P. 217. 